\title{
Analisi Resiko Portofolio Menggunakan Value at Risk dengan Metode Variansi Kovaransi dan Simulasi Historis
}

(Portfolio Risk Analysis Using Value at Risk with the Variance Coverage Method and Historical Simulation)

\section{Norinda Supriyani ${ }^{1}$, Sugiyarto ${ }^{2 *}$}

Program Studi Matematika, Fakultas Sains dan Teknologi Terapan, Universitas Ahmad Dahlan Yogyakarta, Jalan Ringroad Selatan, Kragilan, Tamanan, Banguntapan, Bantul, Yogyakarta, 55191, Indonesia E-mail: sugiyartonf@yahoo.com

* Corresponding Author

\begin{tabular}{|c|c|}
\hline ARTICLE INFO & ABSTRACT \\
\hline \multirow[t]{4}{*}{$\begin{array}{l}\text { Kata Kunci } \\
\text { Portofolio } \\
\text { Variansi Kovaransi } \\
\text { VaR } \\
\text { Keywords } \\
\text { Portfolio } \\
\text { Covarance Variant } \\
\text { VaR }\end{array}$} & $\begin{array}{l}\text { Resiko merupakan sesuatu yang ditanggung seseorang dalam melakukan } \\
\text { aktifitas. Demikian juga investor yang melakukan penanaman modal } \\
\text { (investasi) pasti akan memperhitungkan resiko yang terjadi akibat dari } \\
\text { investasinya. Oleh karena itu, Investor perlu mengetahui cara menghitung } \\
\text { resiko agar dapat mengambil tindakan yang tepat untuk portofolionya, sehingga } \\
\text { mereka dapat memperhitungkan tingkat resiko yang mungkin diperoleh. Salah } \\
\text { satu cara menghitung nilai resiko adalah dengan Value at Risk (VaR). Makalah } \\
\text { ini menyajikan perhitungan VaR, dengan menggunakan metode analisa } \\
\text { variansi kovariansi. Berdasarkan metode ini, nilai resiko dipengaruhi oleh } \\
\text { faktor harga pasar saham, volatilitas harga saham, periode waktu, dan tingkat } \\
\text { kepercayaan yang digunakan. Asumsi yang digunakan pada metode ini adalah } \\
\text { return berdistribusi normal. }\end{array}$ \\
\hline & $\begin{array}{l}\text { Risk is something that is borne by a person in carrying out activities. Likewise, } \\
\text { investors are making investment will certainly take into account the risks } \\
\text { arising from its investment. Therefore, investors need to know how to calculate } \\
\text { risk in order to take appropriate action for their portfolios, so that they can } \\
\text { calculate the level of risk that may be obtained. One way to calculate the value } \\
\text { of risk is by using Value at Risk (VaR). This paper presents the calculation of } \\
\text { VaR, using the analysis method of variance covariance. Based on this method, } \\
\text { the risk value is influenced by the stock market price, share price volatility, time } \\
\text { period, and the level of confidence used. The assumption used in this method is } \\
\text { normal distribution return. }\end{array}$ \\
\hline & This is an open access article under the CC-BY-SA license. \\
\hline & (c) (i) (ㄱ) \\
\hline
\end{tabular}




\section{PENDAHULUAN}

Dalam melakukan investasi, para investor sering kali harus menghadapi berbagai resiko. Resiko adalah selisih antara tingkat pengembalian actual dengan tingkat pengembalian yang diharapkan (expected return)[1]. Dalam menghitung resiko tersebut dikenal dengan simpangan baku (standard of deviation)[2][3][4].

Investor harus memahami elemen dari resiko tersebut supaya resiko tersebut dapat dikelola dengan baik dalam rangka investasi di masa depan yang akan dilakukan[5]. Elemen resiko tersebut yaitu pertama, jangka waktu (time horizon). Jangka waktu pengelolaan resiko tersebut sangat penting karena dengan mengetahui jangka waktu maka investor dapat pengharapan untuk mengelola resiko[6]. Elemen kedua adalah Skenario. Skenario merupakan salah satu elemen dari pengelolaan resiko[7]. Elemen ketiga adalah Ukuran Skenario, merupakan salah satu elemen yang sangat penting dalam pengelolaan resiko.

Elemen keempat adalah patokan (benchmark) dan merupakan elemen resiko yang sangat rendah pemahaman investor dalam area ini untuk pengelolaan resiko[8].

Secara sederhana VaR dapat didefinisikan sebagai estimasi kerugian potensial yang maksimal pada periode tertentu dengan confidence level tertentu dan dalam kondisi pasar yang normal[6]. Dengan demikian, VaR digunakan untuk mengestimasi kerugian maksimal yang bisa saja terjadi pada esok hari, dua hari kemudian, dan seterusnya atau periode waktu tertentu lainnya[6]. Dengan mengetahui VaR berarti dapat diketahui perkiraan kerugian maksimum yang mungkin terjadi sehingga dapat memperkirakan tindakan bagi portofolionya untuk mengurangi resiko.

\section{METODE}

Metode Variansi Kovaransi

Untuk menghitung VaR portofolio, dimisalkan $W_{0}$ adalah investasi awal dan $R_{p}$ adalah tingkat return portofolionya. Nilai portofolio pada akhir periode adalah $W=W_{0}+\left(1+R_{p}\right)$. Nilai ekspektasi dan volatilitas return adalah $\mu$ dan $\sigma$. Dan dimisalkan nilai portofolio pada tingkat kepercayaan $c$ adalah $W^{*}$, di mana $W^{*}=W_{0}\left(1+R_{p}^{*}\right)$. VaR relative diartikan sebagai kerugian (dalam satuan uang) yang relative terhadap mean [9]:

$$
\operatorname{VaR}(\text { mean })=E(W)-W^{*}=-W_{0}\left(R_{p}^{*}-\mu\right)
$$

Jika diasumsikan parameter $\mu$ dan $\sigma$ digunakan untuk return periode harian. Bila perubahan return portofolio di amati pada periode waktu singkat, maka mean diasumsikan nol. Dengan menggunakan persamaan (1.1), dapat dihitung nilai VaR di bawah mean adalah sebagai berikut[10] :

$$
\operatorname{VaR}(\text { mean })=-W_{0}\left(R_{p}^{*}-\mu\right)=W_{0} \alpha \sigma\left(R_{p}\right)
$$

Tanda negatif artinya mengalami kerugian.

Contoh 1 :

Misalkan seorang investor ingin menginvestasikan dananya sebesarnya $\$ 100.000$ pada sebuah portofolio yang terdiri dari sebuah asset tunggal, yaitu saham Microsoft. Di asumsikan return saham tersebut berdistribusi normal. Diketahui $\mu=0,09$ dan $\sigma=0,5$ dan tingkat kepercayaan 95\% $\left(-Z_{0,95}=-1,65\right)$.

$$
\operatorname{VaR}=-1,65 \times 0,5=-0,825
$$

Jadi, kerugian maksimum diharapkan tidak melebihi $\$ 82.500$ dalam jangka waktu 1 hari setelah tanggal 30 Desember 2008 untuk tingkat kepercayaan 95\%. 


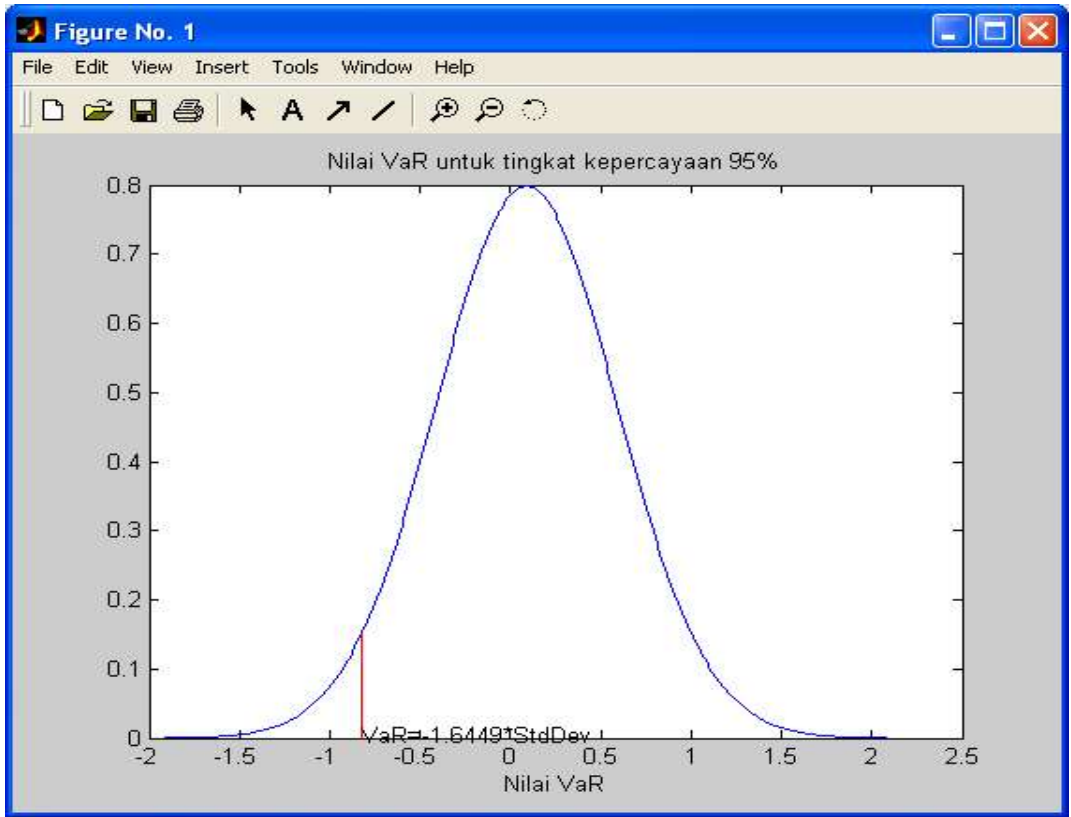

Gambar 1. Nilai VaR pada Kurva Normal dengan Tingkat Kepercayaan 95\%

Metode Simulasi Historis

Selain metode variansi kovariansi nilai VaR dapat dihitung dengan menggunakan metode simulasi historis. Pada metode ini diperlukan data Profit/Loss $(\mathrm{P} / \mathrm{L})$ return portofolionya. Untuk menghitung VaR, terlebih dahulu kita menentukan besarnya tingkat kesalahan $\alpha$. Kemudian membuat simulasi Profit/Loss $(\mathrm{P} / \mathrm{L})$ dari data return dengan rumus sebagai berikut :

$$
P / L_{t}=\sum_{1=1}^{N} w_{i} R_{i, t}
$$

Di mana :

$P / L_{t}$ adalah Profit/Loss pada periode ke $-\mathrm{t}$.

$w_{i}$ adalah bobot asset ke - i pada portofolio.

$R_{i, t}$ adalah return asset ke - $\mathrm{i}$ pada period ke $-\mathrm{t}$.

Setelah itu data $\mathrm{P} / \mathrm{L}$ tersebut diurutkan mulai dari nilai terkecil sampai yang terbesar. Nilai VaR berada pada percentil ke- $(1-\alpha)$ dari data $\mathrm{P} / \mathrm{L}$ tersebut.

Misalkan banyaknya data $\mathrm{P} / \mathrm{L}$ adalah $\mathrm{n}$, bila menggunakan $\alpha=x \%$, maka percentil ke $(1-\alpha)=(1-x \%) * n$.

Nilai VaR dapat dicari melalui persentil. Karena itu menggunakan tingkat kepercayaan $1-x \%$, sehingga nilai VaR berada pada data dengan nomor indeks $=(1-x \%) * n$. Bila angka indeks tersebut tidak bulat, maka dapat digunakan interpolasi linier

\section{HASIL DAN PEMBAHASAN}

Metode Variansi Kovaransi

Untuk menghitung nilai VaR, terlebih dahulu kita hitung komponen-komponen yang diperlukan, yaitu :

1. Tingkat kepercayaan (confidence level) dan jangka waktu (time horizon). Dalam kasus ini, misalnya tingkat kepercayaan $95 \%$ dan menghitung nilai VaR untuk jangka waktu 1 hari.

2. Nilai volatilitas atau standar deviasi dari data. Diperoleh nilai standar deviasi untuk PT. AALI sebesar 3,815\%, PT IDSR sebesar 3,032\%, dan PT INDF sebesar 3,599\% (dapat dilihat pada lampiran II). Misalkan PT AALI adalah saham ke-1, PT IDSR saham ke-2, dan PT INDF saham ke-3, maka dapat ditulis $\sigma_{1}=0,03815, \sigma_{2}=0,03032$, dan $\sigma_{3}=0,03599$. 
3. Bobot (proporsi) dana yang akan ditanamkan untuk masing-masinng asset. Misalkan investor menetapkan besarnya bobot masing-masing asset adalah $w_{1}=0,5, w_{2}=0,025$, dan $w_{3}=0,25$.

4. Nilai korelasi $\rho_{i j}$. Diperoleh nilai korelasi antar asset sebagai berikut :

$$
\begin{aligned}
& \rho_{12}=0,3147 \\
& \rho_{13}=0,3134 \\
& \rho_{23}=0,4355
\end{aligned}
$$

(Korelasi dengan dirinya sendiri $=\rho_{i j}=1$ )

5. Nilai kovariansi $\sigma_{i j}$. Diperoleh nilai kovariansi antar asset sebagai berikut :

$$
\begin{aligned}
& \sigma_{11}=0,00145 \\
& \sigma_{22}=0,00091 \\
& \sigma_{33}=0,00129 \\
& \sigma_{12}=0,00036 \\
& \sigma_{13}=0,00043 \\
& \sigma_{23}=0,00047
\end{aligned}
$$

6. Variansi portofolio $\sigma^{2}\left(R_{p}\right)$. Variansi portofolio diperoleh dari perkalian antara matriks bobot, matriks variansi, dan tanspose matriks bobot.

$$
\sigma^{2}\left(R_{p}\right)=\left[\begin{array}{lll}
0,5 & 0,25 & 0,25
\end{array}\right]\left[\begin{array}{lll}
0,00145 & 0,00036 & 0,00043 \\
0,00036 & 0,00091 & 0,00047 \\
0,00043 & 0,00047 & 0,00129
\end{array}\right]\left[\begin{array}{c}
0,5 \\
0,25 \\
0,25
\end{array}\right]=0,00076
$$

7. Standar deviasi, $\sigma\left(R_{p}\right)$. Standar deviasi portofolio yaitu akar dari variansinya.

$$
\sigma\left(R_{p}\right)=\sqrt{\sigma^{2}\left(R_{p}\right)}=0,0275
$$

8. Nilai investasi awal portofolio, misalkan sebesar $\$ 1.000 .000$. Sehingga diperoleh nilai VaR sebagai berikut :

$$
\operatorname{VaR}=1,65 \times 0,0275 \times \$ 1.000 .000=\$ 45.456
$$

Artinya kerugian maksimum yang diharapkan tidak melebihi $\$ 45.456$ dalam jangka waktu 1 hari setelah tanggal 30 Desember 2008 dengan tingkat kepercayaan 95\%.

Metode Simulasi Historis

Seperti yang dijelaskan bahwa untuk menghitung VaR dengan metode ini, yang diperlukan adalah data Profit/Loss (P/L), yaitu jumlahan dari bobot asset ke - i dikalikan dengan return asset ke - I pada periode $t$.

Langkah selanjutnya adalah mengurutkan data $\mathrm{P} / \mathrm{L}$ mulai dari nilai yang terkecil sampai yang terbesar untuk mencari persentil ke $-\mathrm{i}(1-\alpha)$. Misalkan digunakan $\alpha=0,05$, maka persentilnya ke $-(1-$ $\alpha)=(1-0,05)=(1-0,05) \times 244=231,8$. Jadi, nilai VaR adalah nilai dari data yang berada antara nomor indeks ke 231 dan 232. Salah satu cara mencari nilai yang tepat dapat digunakan interpolasi linier. Diperoleh nilai $\mathrm{VaR}=0,047$. Misalkan dana untuk portofolionya sebesar $\$ 1.000 .000$, maka nilai VaR menjadi :

$$
0,047 \times \$ 1.000 .000=\$ 47.000
$$

Artinya kerugian portofolio yang diharapkan tidak melebihi $\$ 47.000$ dalam jangka waktu satu hari setelah tanggal 30 Desember 2008 dengan tingkat kepercayaan 95\%. 


\section{SIMPULAN}

Dari hasil studi literatur mengenai penghitungan portofolio VaR, penulis dapat menarik kesimpulan yaitu :

1. VaR dapat diaplikasikan untuk berbagi kepentingan diantaranya laporan informasi, evaluasi kinerja pada institusi-institusi keuangan, regulator, perusahaan non keuangan dan manajer portofolio.

2. Pendekatan Variansi Kovariansi membutuhkan matriks untuk menghitung VaR.

3. Pendekatan simulasi historis membutuhkan data Profit/Loss dari waktu yang lalu untuk menghitung VaR.

4. Asumsi pada kedua metode yaitu return berdistribusi normal.

IVaR dan CVaR adalah ukuran penting dalam manajemen portofolio. Keduanya digunakan untuk mengestimasi posisi portofolio yang lebih baik, sehingga dapat mengurangi resiko portofolio.

\section{DAFTAR PUSTAKA}

[1] C. Butler, Mastering Value at Risk: A step-by-step guide to understanding and applying VaR. Financial Times/Prentice Hall, 1999.

[2] K. Dowd, An introduction to market risk measurement. John Wiley \& Sons, 2003.

[3] H. Mausser and D. Rosen, "Beyond VaR: from measuring risk to managing risk," in Proceedings of the IEEE/IAFE 1999 Conference on Computational Intelligence for Financial Engineering (CIFEr)(IEEE Cat. No. 99TH8408), 1999, pp. 163-178.

[4] C. Gourieroux and J. Jasiak, "Value at risk," in Handbook of Financial Econometrics: Tools and Techniques, Elsevier, 2010, pp. 553-615.

[5] T. Eduardus, "Analisis investasi dan manajemen portofolio," Yogyakarta PT. BPFE, 2001.

[6] P. Jorion, Value at risk: the new benchmark for managing financial risk. The McGraw-Hill Companies, Inc., 2007.

[7] C. E. Heckler, "Applied multivariate statistical analysis.” Taylor \& Francis, 2005.

[8] J. Klett, Applied multivariate analysis. New York: McGraw-Hill, 1972.

[9] H. Anton, P. Silaban, and I. N. Susila, Aljabar Linear Elementer. Erlangga, Jakarta, 1987.

[10] H. Anton, “Aljabar Linier Elementer Edisi Ketiga," Terjem. Pantur Silab. dan I. Nyoman Susila. Penerbit Erlangga, Jakarta, 1991. 